\title{
LAJU PERTUMBUHAN ZOOPLANKTON Diaphanosoma sp. DENGAN PEMBERIAN PAKAN KOMBINASI FITOPLANKTON Tetraselmis sp., Nannochloropsis sp. DAN Dunaliella sp. DI LABORATORIUM
}

\author{
Bertha Wina ${ }^{1}$, Sri Murwani ${ }^{1}$, Emy Rusyani \\ 1 Jurusan Biologi FMIPA Universitas Lampung \\ ${ }^{2}$ Balai Besar Pengembangan Budidaya Laut (BBPBL) Lampung \\ Jurusan Biologi FMIPA Universitas Lampung \\ Jl. Soemantri Brojonegoro No.1, Bandar Lampung, Lampung, Indonesia, 35145
}

\begin{abstract}
Abstrak
Diaphanosoma sp. atau dikenal sebagai kutu laut, berpotensi sebagai pakan hidup untuk larva ikan dan udang karena siklus hidupnya relatif singkat sehingga memungkinkan untuk diproduksi secara masal. Untuk mengetahui pengaruh pemberian pakan kombinasi fitoplankton Tetraselmis sp., Nannochloropsis sp. dan Dunaliella sp terhadap laju pertumbuhan populasi Diaphanosoma sp. maka dilakukan serangkaian penelitian pada skala laboratorium dari bulan Maret sampai April 2013 di Laboratorium Pakan hidup Balai Besar Pengembangan Budidaya Laut Lampung dengan menggunakan Rancangan Acak Lengkap dengan 4 perlakuan dan 5 ulangan. Hasil penelitian menunjukkan bahwa kepadatan, $1064 \mathrm{Ind} / \mathrm{L}$ dan pertumbuhan populasi tertinggi, 87,634 \%, terdapat pada kultur yang diberi pakan $50 \%$ Tetraselmis sp. + $25 \%$ Nannochloropsis sp. + $25 \%$ Dunaliella sp.. Hasil analisis proksimat menunjukkan bahwa pakan kombinasi Tetraselmis sp. $50 \%+$ Nannochloropsis sp. $25 \%$ + Dunaliella sp. $25 \%$ memiliki kandungan gizi yang paling baik yaitu protein $44,46 \%$, karbohidrat $10,34 \%$ dan lemak $4,21 \%$.
\end{abstract}

Kata Kunci : Laju pertumbuhan, Diaphanosoma sp., Tetraselmis sp., Nannochloropsis sp., dan Dunaliella sp.

\begin{abstract}
Diaphanosoma sp. which known as sea lice has a potential used as live food for marine fish and shrimp larvae because it has relatively short life cycle and can be mass produced. The purpose of the study was to determine the effect of feeding combination of phytoplankton: Tetraselmis sp., Nannochloropsis sp. and Dunaliella sp. on the population growth rate of Diaphanosoma sp. under laboratory scale. The research was conducted from March to April 2013 in the Laboratory of living food, Center for Mariculture Development (BBPBL) Lampung using completely randomized design (CRD) with 4 treatments and 5 replications. Data were analyzed by using analysis of variance and followed by the Least Significant Difference Test (BNT) at $5 \%$. The results showed that the population density $(1064 \mathrm{Ind} / \mathrm{L})$ and the growth rate $(87,63 \%)$ were highest under food combination of Tetraselmis sp. $50 \%+$ Nannochloropsis sp. $25 \%+$ Dunaliella sp. $25 \%$. In addition, proximate analysis showed that the combination of Tetraselmis sp. $50 \%+$ Nannochloropsis sp. $25 \%+$ Dunaliella sp. $25 \%$ has a good nutritional content namely protein $44,46 \%$, carbohydrate $10,34 \%$ and fat $4,21 \%$.
\end{abstract}

Keywords : Growth rate, Diaphanosoma sp., Tetraselmis sp., Nannochloropsis sp., and Dunaliella sp.

\section{PENDAHULUAN}

Salah satu komponen ekosistem laut yang berfungsi sebagai produsen dan konsumen primer adalah plankton. Plankton dapat dibedakan menjadi dua kelompok besar, yaitu: zooplankton dan fitoplankton. Fitoplankton mampu melakukan fotosintesis sehingga berperan penting sebagai produsen primer, sedangkan zooplankton berperan sebagai konsumen primer (MC Noughton dan Wolf, 1992).

Mudjiman (2004) menyatakan bahwa zooplankton adalah hewan renik yang hidup melayang-layang di perairan dan merupakan konsumen tingkat pertama yang memanfaatkan fitoplankton sebagai pakan. Zooplankton juga menjadi pakan alami bagi konsumen selanjutnya seperti larva ikan dan udang. Salah satu zooplankton yang banyak digunakan sebagai pakan alami yang baik bagi larva ikan dan udang adalah dari ordo Cladocera. Kebanyakan anggota ordo Cladocera hidup di perairan tawar, namun ada juga yang hidup diperairan payau seperti Diaphanosoma sp atau dikenal dengan istilah kutu air laut (Soelistyowati, 1978). Menurut Rusyani dkk (2005) banyak ditemukan kutu air laut (Diaphanosoma sp.) dari keluarga Sididae di perairan sekitar Teluk Lampung, yang akhir-akhir ini dijadikan sebagai 
pakan alternatif pengganti naupli Artemia. Perkembangannya yang cukup singkat, memungkinkan jenis kutu air laut ini dapat diproduksi secara massal sebagai pakan alami larva ikan, udang serta kuda laut sebagai subtitusi Artemia (Thariq dkk., 2007).

\section{BAHAN dan METODE}

Penelitian ini dilaksanakan dari bulan MaretApril 2013 di Laboratorium Pakan hidup (zooplankton) Balai Besar Pengembangan Budidaya Laut (BBPBL) Lampung menggunakan Rancangan Acak Lengkap (RAL) dengan 4 perlakuan dan 5 ulangan yaitu :

(A) Pakan Tetraselmis sp. $50 \%+$ Dunaliella sp. $50 \%$.

(B) Pakan Tetraselmis sp. $50 \%$ + Nannochloropsis sp. $50 \%$.

(C) Pakan Tetraselmis sp. $50 \%+$ Nannochloropsis sp. $25 \%+$ Dunaliella sp. $25 \%$.

(D) Pakan Tetraselmis sp. $100 \%$ sebagai kontrol.
Cara kerja pada penelitian ini adalah menyiapkan pakan uji fitoplankton, kemudian menyaring air laut, dengan penyinaran UV dan merebus air laut. Air laut sebanyak 1,5 liter dimasukkan dalam wadah dengan penambahan $500 \mathrm{ml}$ bibit fitoplankton dan menambahkan pupuk Conwy $1 \mathrm{ml} /$ liter. Membiakkan bibit fitoplankton selama 5-7 hari hingga media kultur berubah warna menjadi hijau tua. Melakukan pengambilan fitoplankton dengan pipet tetes dan perhitungan kepadatan pada haemocytometer setelah itu Memberikan fitoplankton kepada Diaphanosoma sp. Melakukan pengitungan terhadap laju pertumbuhan Diaphanosoma sp.

Pengamatan dan pengumpulan data dilakukan setiap hari selama penelitian. Parameter yang diamati dalam penelitian ini adalah kepadatan populasi Diaphanosoma sp., laju pertumbuhan populasi spesifik, analisa proximat dan kualitas air.

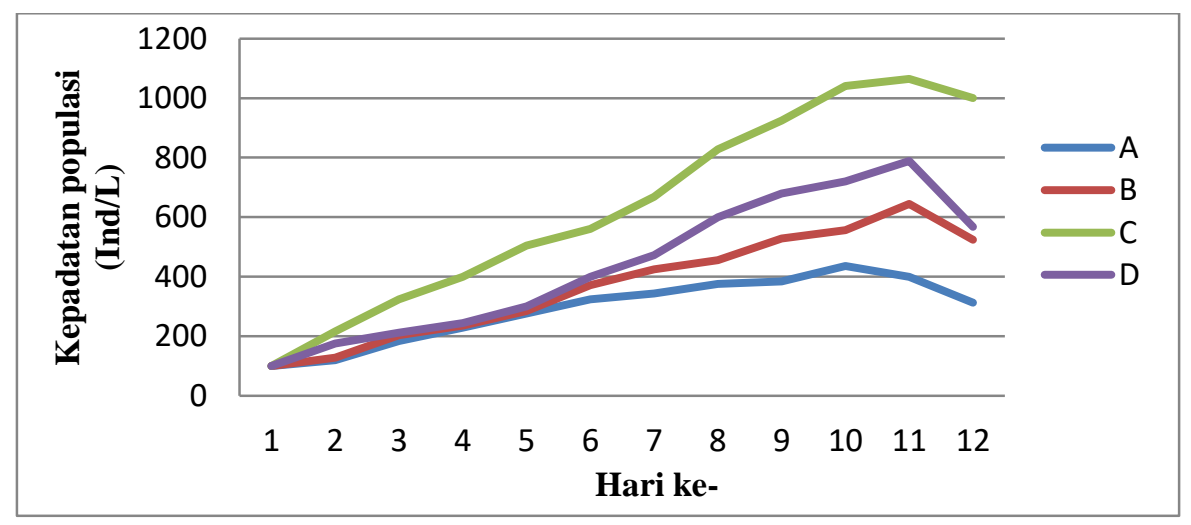

Gambar 8. Grafik kepadatan populasi Diaphanosoma sp.

Keterangan :

(A) Pakan Tetraselmis sp. $50 \%+$ Dunaliella sp. $50 \%$.

(B) Pakan Tetraselmis sp. $50 \%+$ Nannochloropsis sp. $50 \%$.

(C) Pakan Tetraselmis sp. $50 \%$ + Nannochloropsis sp. $25 \%$ + Dunaliella sp. $25 \%$.

(D) Pakan Tetraselmis sp. $100 \%$ sebagai kontrol.

\section{HASIL dan PEMBAHASAN}

\section{Kepadatan Populasi Diaphanosoma sp.}

Hasil pengamatan terhadap data kepadatan populasi Diaphanosoma sp. dapat dilihat pada Gambar 8. Puncak kepadatan populasi tertinggi terjadi pada hari ke-11 yaitu pada kultur perlakuan (C) sebanyak 1064 Ind/L. Sedangkan perlakuan (A) memiliki kepadatan populasi yang terendah yaitu $436 \mathrm{Ind} / \mathrm{L}$. Kepadatan populasi yang berbeda-beda ini diduga karena masing-masing pakan kombinasi memiliki kandungan nutrisi yang tidak sama. Menurut Rusyani dkk. (2005), kandungan nilai nutrisi yang cukup tinggi akan mempengaruhi pertum- buhan dan kemampuan organisme dalam memproduksi telur. Pada perlakuan $\mathrm{C}$ setelah dianalisis proksimat memiliki kandungan nutrisi lemak dan protein yang tinggi yaitu dibandingkan kandungan nutrisi pada perlakuan A, B maupun D. Menurut Djarijah (1995), sumber energi organisme aquatik diperoleh dari protein, lemak dan karbohidrat, dan dimanfaatkan untuk pertumbuhan dan perkembangannya.

Kepadatan populasi Diaphanosoma sp. hari ke12 mengalami penurunan pada masing-masing perlakuan. Hal ini diduga karena kepadatan dari pertumbuhan populasi Diaphanosoma sp. telah mencapai batas pertumbuhan maksimal se- 
hingga ruang gerak menjadi sempit dan terjadi kompetisi antar organisme untuk memperoleh pakan sehinggai hewan yang mampu bersaing akan bertahan hidup, sedangkan bagi yang tidak mampu bersaing akan mati. Selanjutnya dikatakan bahwa perkembangan populasi dapat terjadi dengan adanya per-ubahan-perubahan fisik lingkungan dan interaksi antara individu untuk mendapatkan pakan.
Adapun hasil uji statistik yang telah dilakukan terdapat pada Tabel 5. Pemberian pakan kombinasi fitoplankton dari Tetraselmis sp., Nannochloropsis sp. dan Dunaliella sp. berbeda sangat nyata $(p<0,05)$ pada pertumbuhan populasi spesifik Diaphanosoma sp. artinya perlakuan pemberian pakan kombinasi tersebut berpengaruh nyata pada pertumbuhan populasi spesifik Diaphanosoma sp. pada masing-masing perlakuan.

Tabel 5. Kepadatan Populasi Diaphanosoma sp. (ind/L)

\begin{tabular}{|c|c|c|c|c|c|c|c|}
\hline \multirow{2}{*}{ Perlakuan } & \multicolumn{5}{|c|}{ Ulangan } & \multirow{2}{*}{ Jumlah } & Rerata \pm SD \\
\cline { 2 - 8 } & 1 & 2 & 3 & 4 & 5 & Jumlan \\
\hline A & 38 & 28 & 34 & 36 & 32 & 168 & $33.6 \pm 3,85 \mathrm{a}$ \\
\hline B & 57,73 & 45,45 & 54,54 & 50,9 & 43,64 & 252,26 & $50.452 \pm 5,94 \mathrm{~b}$ \\
\hline C & 92,73 & 96,36 & 80 & 94,54 & 94,54 & 438,17 & $87.634 \pm 9,74 \mathrm{~d}$ \\
\hline D & 61,81 & 63,64 & 61,81 & 69,09 & 56,36 & 312,71 & $62.542 \pm 4,56 \mathrm{c}$ \\
\hline
\end{tabular}

Keterangan : Angka rata-rata yang diikuti oleh notasi yang berbeda berarti berbeda nyata pada taraf $5 \%$.
(A) Pakan Tetraselmis sp. $50 \%+$ Dunaliella sp. $50 \%$.
(B) Pakan Tetraselmis sp. $50 \%$ + Nannochloropsis sp. $50 \%$
(C) Pakan Tetraselmis sp. $50 \%+$ Nannochloropsis sp. $25 \%+$ Dunaliella sp. $25 \%$.
(D) Pakan Tetraselmis sp. $100 \%$ sebagai kontrol.

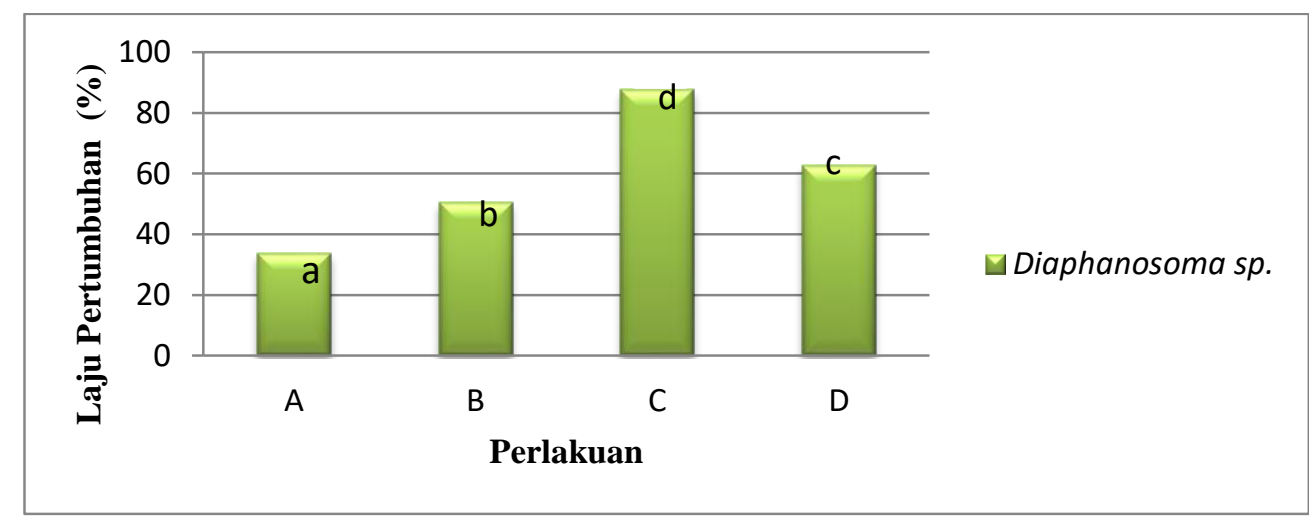

Gambar 9. Diagram laju Pertumbuhan Diaphanosoma sp.

Keterangan : Grafik yang diikuti oleh notasi yang berbeda berarti berbeda nyata pada taraf $5 \%$.

(A) Pakan Tetraselmis sp. $50 \%+$ Dunaliella sp. $50 \%$.

(B) Pakan Tetraselmis sp. $50 \%+$ Nannochloropsis sp. $50 \%$.

(C) Pakan Tetraselmis sp. $50 \%$ + Nannochloropsis sp. $25 \%$ + Dunaliella sp. $25 \%$

(D) Pakan Tetraselmis sp. $100 \%$ sebagai control.

\section{Laju Pertumbuhan Diaphanosoma sp.}

Laju pertumbuhan Diaphanosoma sp. yang dipelihara pada media kultur dengan air laut steril selama 12 hari dengan masing-masing perlakuan terdapat pada (Gambar 9). Rata-rata laju pertumbuhan Diaphanosoma sp. selama penelitian dari yang terendah sampai tertinggi adalah pada perlakuan A (33,60\%), B (50,45 \%), D $(62,54 \%)$, dan C $(87,634 \%)$.

Hasil uji statistik menunjukkan bahwa pemberian pakan kombinasi fitoplankton dari Tetraselmis sp., Nannochloropsis sp. dan Dunaliella sp. berbeda sangat nyata $(p<0,05)$ pada laju pertumbuhan populasi Diaphanosoma sp. Ting- ginya laju pertumbuhan populasi Diaphanosoma sp. pada perlakuan C diduga karena pengaruh dari perbedaan fase pertumbuhan fitoplankton dalam media kultur Diaphanosoma sp. yaitu fase eksponensial. Pada fase ini selsel telah mengalami perkembangan dengan baik, sehingga pertumbuhannya cepat dan konstan. Hal ini sesuai dengan pendapat Isnansetyo dan Kurniastuty (1995) bahwa pada fase eksponensial diawali oleh pembelahan sel dengan laju pertumbuhan konstan, pada kondisi kultur yang optimum, laju pertumbuhan pada fase ini mencapai maksimal. 
Perbedaan kepadatan populasi Diaphanosoma sp. diduga karena proses penebaran induk, yaitu pada jumlah telur atau anakan yang berada di dalam kantung telur induk Diaphanosoma sp. Selain itu mungkin banyak yang dipengaruhi oleh kandungan nutrisi pakan yang ada di dalam media kultur pada masing-masing perlakuan. Menurut Thariq $d k k$ (2007) bahwa telur Cladocera yang telah menetas menjadi naupli akan mencapai perkembang-an penuh di ovarium bila nutrisinya bagus.

Laju pertumbuhan populasi spesifik Diaphanosoma sp. pada pemberian pakan kombinasi fitoplankton pada perlakuan $C$ tertinggi dibandingkan pada perlakuan A, B, dan D. Hal ini diduga karena kandungan nutrisi pada perlakuan $C$ lebih tinggi yaitu pada kandungan lemak dan protein dalam menunjang laju pertumbuhan dan perkembangan Diaphanosoma sp. Selain itu, ketersediaan pakan pada media pe- meliharaan diduga dimanfaatkan secara maksimum oleh Diaphanosoma sp. untuk pertumbuhannya. Dugaan ini berdasarkan pendapat Novianty (2000) bahwa pakan yang banyak mengandung lemak dan protein diberikan kepada Crustaceae selain diubah menjadi energi untuk pergerakan, keseimbangan dan metabolisme, juga digunakan untuk pertumbuhan dan perkembangan dari Diaphanosoma sp.

Selain itu kualitas air juga mempenga-ruhi laju pertumbuhan Diaphanosoma sp. Kualitas air media pemeliharaan yang optimal juga sangat mendukung perkembangan mengatakan bahwa dalam kultur fitoplankton harus dijaga benar banyaknya sinar, suhu, salinitas dan $\mathrm{pH}$ karena faktor-faktor ini menentukan hasil percobaan. Sisa pakan yang tidak termakan dan tidak adanya pergantian air akan menyebabkan berubahnya kondisi media pemeliharaan.

Tabel 6. Kandungan Gizi Pakan Kombinasi Fitoplankton (\%) (Lampiran Analisis proksimat hasil konversi dari berat kering, 2013)

\begin{tabular}{|c|l|c|c|c|c|c|c|}
\hline No & \multicolumn{1}{|c|}{ Nama Sampel } & Air & Abu & Protein & Lemak & Serat Ksr & Karbohidrat \\
\hline 1 & $\begin{array}{l}\text { (A) Tetraselmis sp. } \\
50 \%+D u n a l i e l l a ~ 50 \%\end{array}$ & 10.000 & 353.158 & 405.732 & 22.826 & 46.712 & 154.572 \\
\hline 2 & $\begin{array}{l}\text { (B) Tetraselmis sp. } \\
50 \%+\text { Nanno Chloropsis 50\% }\end{array}$ & 10.000 & 346.426 & 434.351 & 39.758 & 42.731 & 126.734 \\
\hline 3 & $\begin{array}{l}\text { (C) Tertraselmis sp. } \\
50 \%+\text { Nanno Chloropsis } \\
25 \%+D u n i l i e l l a ~ 25 \%\end{array}$ & 10.000 & 343.350 & 444.590 & 42.058 & 46.615 & 103.387 \\
\hline 4 & $\begin{array}{l}\text { (D) Kontrol Tetraselmis sp } \\
100 \%\end{array}$ & 10.000 & 352.457 & 429.250 & 35.935 & 45.165 & 137.193 \\
\hline
\end{tabular}

Sumber : Laboratorium Teknologi Hasil Pertanian Politeknik Negeri Lampung (2013).

\section{Analisis Proksimat}

Hasil analisis proksimat yang telah dilakukan di Politeknik Negeri Lampung terdapat pada Tabel 6. Kandungan air dan kandungan abu pada masing-masing pakan kombinasi relatif sama. Namun kandungan protein berbeda-beda, yang tertinggi terdapat pada pakan kombinasi $C$ yaitu $44.46 \%$ sedangkan protein terendah terdapat pada pakan kombinasi A yaitu $40,57 \%$.

Pakan kombinasi $\mathrm{C}$ memiliki kandungan lemak tertinggi yaitu $4,21 \%$ dan pakan kombinasi $D$ memiliki kandungan lemak terendah yaitu lemak 2,28\%. Kandungan serat relatif sama. Namun kandungan karbohidrat pada masingmasing pakan kombinasi berbeda-beda, kombinasi $A$ memiliki kandungan tertinggi yaitu $15,46 \%$, dan yang terendah pada kombinasi $C$ yaitu $10,34 \%$.

\section{Kualitas Air Media Pemeliharaan}

Kualitas air yang diukur selama penelitian adalah suhu, salinitas, dan oksigen terlarut (Tabel 7). Pengukuran ini dilakukan tiga kali selama 12 hari yaitu di awal, pertengahan dan akhir penelitian. Hasil pengukuran $\mathrm{pH}$, serta amoniak disajikan pada Tabel 8.

Hasil pengukuran menunjukkan bahwa suhu air media pemeliharaan selama pengamatan berkisar antara $25-29{ }^{\circ} \mathrm{C}$. Kisaran suhu ini masih berada dalam kisaran yang dapat ditolerir bagi pertumbuhan Diaphanosoma sp. Menurut Rusyani $d k k$ (2005), kisaran suhu optimal untuk pertumbuhan Diaphanosoma sp. adalah 25$29,5{ }^{\circ} \mathrm{C}$. Suhu adalah faktor fisika yang dapat mempengaruhi aktivitas dan metabolisme serta perkembangan organisme. Suhu berpengaruh terhadap proses pertukaran zat atau metabolisme suatu makhluk hidup. Saat suhu tinggi metabolisme dan respirasi organisme air meningkat cepat dan berakibat pada peningkatan konsumsi oksigen yang berdampak pada menurunnya kadar oksigen terlarut (Effendi, 2000). 
Tabel 7. Hasil pengukuran suhu, salinitas, dan oksigen terlarut.

\begin{tabular}{|c|c|c|c|}
\hline Perlakuan & Suhu $\left({ }^{\circ} \mathrm{C}\right)$ & Salinitas $(\% \circ)$ & DO $(\mathrm{mg} / \mathrm{l})$ \\
\hline $\mathrm{A}$ & $25-28$ & $25-27$ & $4,28-5,75$ \\
\hline $\mathrm{B}$ & $26-29$ & $25-27$ & $4,18-5,93$ \\
\hline $\mathrm{C}$ & $25-29$ & $25-26$ & $4,21-5,81$ \\
\hline D & $26-28$ & $25-27$ & $4,24-5,90$ \\
\hline Kelayakan & $\begin{array}{c}25-29,5 \\
\text { (Rusyani } \\
d k k .\end{array}$ & $\begin{array}{c}25-35 \\
\text { (Thariq } d k k ., \\
2007)\end{array}$ & $\begin{array}{c}4,18-5,94 \\
\text { (Mubarak } \\
d k k ., 2008)\end{array}$ \\
\hline
\end{tabular}

Keterangan :

(A) Pakan Tetraselmis sp. $50 \%+$ Dunaliella sp. $50 \%$.

(B) Pakan Tetraselmis sp. $50 \%+$ Nannochloropsis sp. 50 $\%$.

(C) Pakan Tetraselmis sp. $50 \%+$ Nannochloropsis sp. 25 $\%+$ Dunaliella sp. $25 \%$.

(D) Pakan Tetraselmis sp. $100 \%$ sebagai control.

Salinitas air selama penelitian adalah berkisar 25-27 \%o dan merupakan salinitas yang normal untuk pertumbuhan Diaphanosoma sp. Thariq dkk (2007), menyatakan bahwa kisaran Salinitas yang luas (euryhaline) yaitu berkisar antara 25-35\%o.

Tabel 8. Hasil pengukuran Amoniak dan $\mathrm{pH}$

\begin{tabular}{|c|c|c|c|c|}
\hline \multirow{2}{*}{ Perlakuan } & \multicolumn{2}{|c|}{$\mathrm{pH}$} & \multicolumn{2}{c|}{ Amoniak (mg/L) } \\
\cline { 2 - 5 } & Awal & Akhir & Awal & Akhir \\
\hline A & 7 & 7 & 0,016 & 0,011 \\
\hline B & 7 & 7 & 0,014 & 0,019 \\
\hline C & 7 & 7 & 0,012 & 0,017 \\
\hline D & 7 & 8 & 0,022 & 0,028 \\
\hline Kelayakan & \multicolumn{2}{|c|}{$\begin{array}{c}6,5-8,5 \\
\text { (Rusyani dkk., } \\
\text { 2005) }\end{array}$} & \multicolumn{2}{c}{$\begin{array}{c}\text { (Supriya dkk. } \\
\text { 2002) }\end{array}$} \\
\hline
\end{tabular}

Keterangan :

(A) Pakan Tetraselmis sp. $50 \%+$ Dunaliella sp. $50 \%$.

(B) Pakan Tetraselmis sp. $50 \%+$ Nannochloropsis sp. 50 $\%$.

(C) Pakan Tetraselmis sp. $50 \%+$ Nannochloropsis sp. 25 $\%+$ Dunaliella sp. $25 \%$.

(D) Pakan Tetraselmis sp. $100 \%$ sebagai kontrol.

Selain suhu dan salinitas, kadar oksigen terlarut juga menjadi faktor penting untuk kehidupan Diaphanosoma sp. Menurunnya kadar oksigen terlarut dapat disebabkan oleh proses metabolisme dan respirasi oleh organisme akuatik, atau dekomposisi oleh mikroba. Diaphanosoma sp. memiliki kemampuan tinggi dalam mentolerir oksigen terlarut yang rendah (Kokarkin dan Prastowo, 1998). Novianty (2000), menyatakan bahwa oksigen terlarut dalam air diperoleh dari proses difusi atmosfer, hasil fotosintesis, atau melalui aerasi.

$\mathrm{pH}$ media pemeliharaan selama penelitian pada setiap perlakuan masih sesuai untuk kebutuhan hidup Diaphanosoma sp. meskipun ada kecenderungan menurun pada akhir penelitian. Kisa- ran nilai $\mathrm{pH}$ ini masih berada dalam kisaran optimal untuk pertumbuhan Diaphanosoma sp. yaitu $6,5-8,5$ (Rusyani $d k k ., 2005$ ).

Hasil pengukuran amoniak pada media pemeliharaan pada awal penelitian adalah antara 0,01-0,22 $\mathrm{mg} / \mathrm{l}$ dan pada akhir penelitian cenderung meningkat yaitu berkisar antara 0,01-0,02 $\mathrm{mg} / \mathrm{l}$. Hal ini berhubungan dengan lebih tingginya nilai $\mathrm{pH}$ pada perlakuan D. Semakin tinggi nilai $\mathrm{pH}$ suatu perairan maka kadar amoniak $\left(\mathrm{NH}_{3}\right)$ semakin tinggi. Peningkatan kadar amoniak yang bersifat racun dalam perairan akan menyebabkan terjadinya akumulasi amoniak pada tubuh organisme akuatik yang berdampak pada kematian (Buwono, 2002). Menurut Supriya dkk (2002) kadar amoniak dalam media pemeliharaan tidak boleh lebih dari 0,6 $\mathrm{mg} / \mathrm{l}$ karena dapat membahayakan organisme. Amoniak $\left(\mathrm{NH}_{3}\right)$ yang terkandung dalam suatu perairan merupakan salah satu hasil dari proses penguraian bahan organik. Amoniak biasanya timbul dari aktifitas dekomposisi jasad renik terhafdap kotoran organisme dan bahan organik yang lain.

\section{KESIMPULAN}

Pemberian pakan kombinasi fitoplankton Tetraselmis sp. $50 \%+$ Nannochloropsis sp. $25 \%+$ Dunaliella sp. $25 \%$ menghasilkan kepadatan populasi dan laju pertumbuhan populasi Diaphanosoma sp. tertinggi sedangkan laju pertumbuhan populasi Diaphanosoma sp. yang terendah terdapat pada pakan kombinasi fitoplankton Tetraselmis sp. $50 \%+$ Nannochloropsis sp. $25 \%+$ Dunaliella sp. $25 \%$ yaitu $33.6 \%$.

\section{DAFTAR PUSTAKA}

Buwono, I. D. 2002. Tambak Udang Windu : Sistem Pengelolaan Berpola Intensif. Kanisius. Yogyakarta..

Djarijah. A. S. 1995. Pakan Ikan Alami. Kanisius : Yogyakarta.

Effendi, H. 2000. Telaah Kualitas Air : Bagi Pengelolaan Sumberdaya dan Lingkungan Perairan. Jurusan Manajemen Sumberdaya Perairan IPB. Bogor.

Isnansetyo, A. dan Kurniastuty. 1995. Teknik Kultur Fitoplankton dull Zooplankton: Pakan Alami untuk Pembenihan Organisme Laut, Kanisius : Yogyakarta.

Kokarkin, C. dan B. W. Prastowo, 1998. Manfaat Strategis kutu air, Diaphanosoma celebensis dalam Budidaya dan Managemen Lingkungan Pantai". Balai Budidaya Air Payau Jepara.

Mudjiman, A. 2004. Makanan Ikan (edisi revisi). Penebar Swadaya. Jakarta. 
Novianty, S. 2000. Pengaruh Kepadatan Chaetoceros sp. (Bacillariophyceae) Terhadap Laju Pertumbuhan Cyclops sp (Crustaceae) Dalam Kondisi Laboratorium. Skripsi. Jurusan BiologiFMIPA Universitas Sriwijaya. Inderalaya.

Romimohtarto, K., dan Juwana. S 2001. Biologi Laut: IImu Pengetahuan Tentang Biota Laut. Djambatan. Jakarta.

Rusyani, E., L. Erawati. dan A. Hermawan. 2005. Budidava Zooplankton dalam Pembenihan Kuda Laut. Balai Budidava Laut Lampung Dirjen Perikanan Budidava DKP. Lampung.

Sachlan, M. 1982. Planktonologi. Fakultas perternakan dan Perikanan Universitas Dipenegoro. Semarang.

Soelistyowati. 1978. Pengaruh Beberapa Jenis Pakan Terhadap Pertumbuhan Diaphanosoma sp. Skripsi. Universitas Diponegoro. Semarang.

Supriya, A. Hafiz dan Mustamin. 2002. Persyaratan Budidaya "Zooplankton dalam Budidava Fitoplankton dan Zooplankton. Balai Budidava Laut Lampung. Lampung.

Tjahjo, L. Erawati dan Hanung. 2002. Biologi Fitoplankton dalam Budidaya Fitoplankton dan Zooplankton. Balai Budidaya Laut Lampung. Lampung.

Thariq, M., V. Retno., S. Antoro, dan L. Erawati. 2007. Biologi Fitoplankton dan Zooplankton dalam Budidaya Fitoplankton dan Zooplankton. Balai Besar Pengembangan Budidaya Laut Lampung. Lampung. 